\title{
Identifikasi Mindset Kewirausahaan Masyarakat Daerah Semau Nusa Tenggara Timur
}

\section{Dyna Rachmawati ${ }^{1}$, Diyah Tulipa ${ }^{2}$, Ignatius Srianta ${ }^{3}$, Lena Ellitan ${ }^{4}$, Andrew Joewono ${ }^{5}$, Mudjilah Rahayu ${ }^{6}$}

\author{
Universitas Katolik Widya Mandala Surabaya \\ dyna@ukwms.ac.id ${ }^{1}$, diyah@ukwms.ac.id ${ }^{2}$, srianta_wm@yahoo.com ${ }^{3}$, lena@ukwms.ac.id ${ }^{4}$, \\ andrew_sby@yahoo.com ${ }^{5}$,rahayu@ukwms.ac.id ${ }^{6}$
}

\begin{abstract}
Semau is an island located in the western part of Timor island. Semau is a sub-district located in Kupang Regency. This island has natural wealth that has not yet been widely utilized. Semau produces red onions with high quality because of the low water content. The great potential for developing Semau must also be balanced with the development of the potential of competent human resources to manage these natural resources. Therefore, this community service activity aims to change the mindset of the community to have an entrepreneurial mindset. The establishment of an entrepreneurial mindset in the community service activities is carried out through the development of entrepreneurial character. The methods conducted to develop entrepreneurial character consist of 3 stages: focus group discussion, training to make and pack fried onions, and in-depth interview. The results conclude that participants have had 6 characters from 7 entrepreneurial characters. The characters are self-confidence, task-oriented and results, risk-takers, leadership, future-oriented, and honest and diligent. While the character of originality/different from before and others still needs to be developed in Semau community.
\end{abstract}

Keywords: Entrepreneurial mindset; Entrepreneurial character development; Semau.

\begin{abstract}
Abstrak
Semau adalah pulau yang terletak di barat pulau Timor. Semau berada di Kabupaten Kupang. Pulau ini memiliki kekayaan alam yang belum dimanfaatkan secara optimal. Semau menghasilkan bawang merah dengan kualitas tinggi karena kandungan air rendah. Potensi besar dalam mengembangkan Semau harus diimbangi dengan pengembangan kompetensi masyarakatnya sehingga dapat mengelola kekayaan alamnya secara optimal. Oleh karena itu, kegiatan pengabdian kepada masyarakat ini mempunyai tujuan untuk mengubah mindset atau pola pikir masyarakat Semau menjadi mindset kewirausahaan. Pembentukan mindset kewirausahaan pada kegiatan pengabdian kepada masyarakat ini dilakukan dalam bentuk pengembangan karakter wirausaha. Metode dalam pengembangan karakter wirausaha dilakukan dalam 3 tahapan yaitu: focus group discussion, pelatihan pembuatan bawang goreng dan pengepakannya sebagai produk jual, dan indepth interview. Hasil kegiatan ini menunjukkan bahwa masyarakat Semau mempunyai 6 dari 7 karakter sebagai wirausaha. Karakter tersebut adalah percaya diri, berorientasi pada hasil, pengambil risiko, kepemimpinan, berorientasi masa depan, jujur dan tekun. Sedangkan karakter orisinil berbeda dari produk yang sudah ada atau lain dari yang lain masih perlu dikembangkan dalam masyarakat Semau.
\end{abstract}


Kata Kunci: Mindset kewirausahaan; Pengembangan karakter wirausaha; Semau.

\section{A. PENDAHULUAN}

\begin{abstract}
Pembangunan sebuah daerah menjadi
\end{abstract} sebuah lingkaran yang rumit untuk diputuskan mana yang akan diprioritaskan antara pengembangan infrastruktur, pengembangan potensi ekonomi sumber daya alam atau pengembangan sumber daya manusia. Pembangunan daerah selalu berputar pada lingkaran yang tidak pernah dimulai dari awal pengembangan daerah tersebut. Akibatnya, potensi daerah yang ada semakin tergilas oleh kemajuan dan perkembangan perekonomian secara nasional sehingga daerah masih tetap menjadi daerah yang belum mampu menggali potensi ekonomi daerah tersebut. Kondisi seperti ini banyak dialami oleh berbagai daerah di Indonesia, bukan karena masyarakat yang tidak mampu melihat potensi daerah, masyarakat hanya memerlukan trigger dan penyemangat untuk mulai menggali potensi daerah tersebut.

Penggalian potensi ekonomi sumber daya alam seyogyanya dibarengai dengan perubahan pola pikir masyarakat yang termotivasi untuk memulai sebuah lompatan pada kuantum pola pikir yang lebih tinggi. Penggalian potensi ekonomi tidak hanya dilakukan dengan mengambil dan mengkonsumsi namun berpikir ke langkah mengambil, mengolah (berproduksi) untuk konsumsi dan memenuhi kebutuhan masyarakat di luar daerah. Oleh karena itu perlu adanya pelopor dan penggerak untuk memberikan motivasi tidak hanya sebatas pengetahuan belaka namun menanamkan sebuah karakter yang mampu melihat peluang dan menangkap peluang sebagai landasan untuk melakukan perubahan.
Pulau Semau, sebuah pulau kecil di bagian Timur Indonesia. Pulau Semau terletak di Kabupaten Kupang propinsi Nusa Tenggara Timur (NTT), merupakan daerah yang memiliki potensi alam yang secara ekonomis siap untuk dikembangkan. Pulau ini dibagi menjadi dua kecamatan, yaitu: Semau dan Semau Selatan. Masyarakat Semau mempunyai mata pencaharian utama sebagai petani dan nelayan. Hasil pertanian yang menjadi unggulan masyarakat adalah bawang merah. Bawang merah yang berasal dari pulau ini mempunyai kualitas tinggi karena kadar airnya rendah. Penggarapan tanah pertanian dilakukan pada musim hujan, sedangkan pada musim kemarau masyarakat melakukan kegiatannya sebagai nelayan. Bawang merah dan ikan laut langsung dijual kepada pedagang yang datang dari Kupang atau dibawa sendiri oleh masyarakat ke Kupang. Masyarakat masih belum mengolah bawang merah dan hasil tangkapan laut lebih lanjut sehingga mampu memberikan nilai tambah bawang merah dan hasil tangkapan laut.

Bawang merah yang menjadi andalan mengalami penurunan harga, sehingga petani mengalami kerugian. Selain itu, petani bawang merah terbiasa membuang bawang merah yang cacat karena tergores pisau pada saat memanen dan membersihkan bawang merah tersebut. Tingkat kecacatan bawang merah tersebut sampai $10 \%$ dari 5,6 ton setiap kali panen dari satu orang petani, berdasarkan hasil wawancara dengan petani bawang merah (Tulipa dkk., 2017). Fakta di atas menunjukkan bahwa masyarakat Semau masih mempunyai pemikiran tradisional dalam mengelola hasil pertanian dan tangkapan laut. Oleh karena itu perlu adanya 
pengembangan potensi masyarakat untuk mengelola hasil pertanian dan tangkapan lautnya menjadi produk olahan yang dapat memberikan nilai ekonomi lebih tinggi. Pengembangan potensi masyarakat diawali dengan perubahan mindset atau pola pikir perilaku dari mengambil menjadi mengolah sehingga memberikan nilai tambah.

Teori perilaku menunjukkan bahwa ketika seseorang melakukan sebuah tindakan (konatif) maka langkah awal sebelum bertindak adalah berpikir (kognitif) dan merasakan (afeksi) terhadap sebuah obyek yang menjadi dasar tindakannya (Schiffman dan Leslie, 2007:511). Konsep dasar yang menjelaskan hubungan antara manusia dengan lingkungan dalam membentuk perilaku dikemukakan oleh Woodworth pada tahun 1928 (Salim, 2008). Konsep tersebut menjelaskan bahwa perubahan perilaku dimulai dari perubahan pola pikir.

Pola pikir yang mampu untuk menangkap peluang dan memanfaatkan peluang sebagai langkah perubahan perilaku nampak pada perilaku wirausahawan (Drucker, 1985:100). Oleh karena itu pengembangan perilaku diawali dengan pengembangan mindset atau pola pikir wirausaha.

Pendidikan kewirausahaan adalah usaha terencana dan aplikatif untuk meningkatkan pengetahuan, intensi/niat dan kompetensi untuk mengembangkan potensi dengan diwujudkan dalam perilaku kreatif, inovatif dan berani mengelola resiko. Pendidikan kewirausahaan berupaya meningkatkan kesadaran akan pentingnya karakter kewirausahaan (kreatif, inovatif dan berani mengelola resiko) (Gunadhi, 2013:17). Pola pikir entrepreneur menonjol dalam banyak hal. Dalam masalah konsumsi, seorang entrepreneur berkarakter produktif bukan konsumtif. Seorang entrepreneur selalu berusaha mencari cara baru untuk meningkatkan utilitas sumber daya secara efisien (Sandiasa, 2009:10). Pengusaha selalu mencari alternatif bila sumber daya yang ada terbatas, cenderung menjadi job creator daripada sekadar job seeker. Semua karakter tersebut disebabkan oleh jumlah total pola pikir positif, kreatif, keuangan, dan pola pikir produktif yang dimilikinya. Oleh karena itu dalam pendidikan kewirausahaan perlu diakselerasi dengan pengalaman dan mindset atau pola pikir seorang wirausaha.

Identifikasi mindset atau pola pikir perilaku kewirausahaan pada masyarakat Semau mempunyai tujuan utama untuk mengembangkan daerah Semau. Tujuan utama tersebut dapat tercapai apabila beberapa petani bawang merah menjadi pengusaha bawang goreng. Kegiatan pengembangan daerah ini dilakukan melalui tiga tahapan. Tahapan pertama dalam bentuk focus group discussion (FGD) yang didasarkan pada teknik ZMET (KhooLatimore, Thyne, dan Robertson, 2009: 139154). Teknik ini bertujuan untuk mengetahui mindset atau pola pikir masyarakat Semau yang menjadi partisipan mengenai karakter yang harus dimiliki oleh seorang pengusaha. Tahapan kedua dalam bentuk pelatihan pembuatan bawang goreng, dan pengemasannya sehingga dapat menjadi produk layak jual. Tahapan ini bertujuan untuk memberikan pengalaman bagi partisipan dalam melakukan proses produksi. Tahapan ketiga adalah kegiatan wawancara dengan partisipan tertentu. Partisipan tertentu adalah partisipan yang dipilih karena memiliki karakter wirausaha paling menonjol. Mereka diharapkan dapat menjadi influencer mindset kewirausahaan bagi masyarakat sekitarnya. Hasil pelaksanaan ketiga tahapan tersebut menunjukkan bahwa masyarakat Semau mempunyai potensi untuk menjadi wirausaha. Produk pertama yang dihasilkan adalah bawang goreng. Produk bawang goreng yang dihasilkan oleh masyarakat Semau mempunyai target pasar 
utama yaitu: wisatawan. Produk bawang goreng mulai dipasarkan pada acara Wisata Semau yang diadakan oleh Kabupaten Kupang bulan Oktober 2018 dan kegiatan gereja pada bulan Desember 2018.

\section{B. PELAKSANAAN DAN METODE}

Metode yang digunakan dalam kegiatan pengabdian kepada masyarakat ini adalah community development. Community development merupakan metode yang melibatkan masyarakat atau komunitas secara aktif dalam mengupayakan kesejahteraannya (Phillips dan Pittman, 2009:5). Community development atau pengembangan komunitas daerah Semau dilakukan dalam tiga tahapan kegiatan yaitu: (1) focus group discussion (FGD), (2) pelatihan pembuatan dan pengemasan bawang goreng, dan (3) in-depth interview (Vincent, 2009: 138).

Tahapan pertama adalah FGD. Pelaksanaan FGD didasarkan pada teknik ZMET. ZMET merupakan teknik yang biasa digunakan oleh pemasar untuk mengetahui pola pikir dan karakter seorang konsumen dalam mengambil keputusan pembelian. Teknik ini dianggap tepat untuk memberikan pemahaman pola pikir masyarakat Semau mengenai karakter-karakter dasar yang harus dimiliki oleh pengusaha.

Pengusaha harus mempunyai 7 karakter dasar yaitu: percaya diri, orientasi tugas dan hasil, pengambil risiko, kepemimpinan, orisinalitas, orientasi masa depan, dan jujur (Suryana, 2001:8). Percaya diri yaitu keyakinan, kemandirian, individualitas serta optimisme untuk menghasilkan sebuah ide dan berkarya. Wirausaha harus mempunyai karakter percaya diri dalam menjalankan usahanya. Karakter ini merupakan modal dasar seorang wirausaha. Berorientasi tugas dan hasil merupakan sifat seorang pengusaha yang memiliki kebutuhan pengakuan atas prestasi yang dicapainya, berorientasi pada keuntungan usaha yang dilakukan, memiliki ketekunan dan ketabahan, memiliki tekad yang kuat, suka bekerja keras, memiliki inisiatif untuk memulai sesuatu dan energik. Pengambil risiko adalah sifat seseorang yang berani mengambil risiko atas keputusannya. Seorang wirausahan merupakan seseorang yang berani mengambill risiko dengan dasar perhitungan yang cukup dan menyukai tantangan. Kepemimpinan yaitu kemampuan untuk memimpin orang lain. Wirausaha diharapkan dapat bertingkah laku sebagai pemimpin, bergaul dengan orang lain dan suka terhadap saran dan kritik yang membangun yang diberikan kepadanya. Orisinalitas merupakan kemampuan wirausaha untuk melakukan inovasi dan kreatifitas, fleksibel serba bisa serta memiliki jaringan usaha yang kuat. Beorientasi masa depan adalah seorang pengusaha hendaknya mampu berpikir jauh ke depan, berjaga-jaga dan mempersiapkan segala kemungkinan yang bisa terjadi dengan melakukan berbagai prediksi. Jujur dan tekun adalah sifat utama yang harus dimiliki oleh seorang wirausaha dengan berkeyakinan bahwa hidup ini sama dengan kerja.

Teknik ZMET menggunakan metafora dalam bentuk gambar yang menunjukkan masing-masing 7 karakter dasar pengusaha. Pelaksanaan pada tahapan ini membutuhkan waktu satu hari penuh. Partisipan dibagi dalam 5 kelompok, yang masing-masing kelompok terdiri dari 6 orang partisipan. Setiap kelompok mempunyai satu orang fasilitator. Fasilitator adalah pihak yang melakukan kegiatan pengabdian kepada masyarakat. Fasilitator mempunyai tugas utama untuk menunjukkan gambar/simbol. Gambar yang digunakan untuk kepentingan FGD ini sebanyak 14 gambar. 2 gambar menunjukkan satu karakter. Gambar-gambar tersebut dapat dipilih oleh masing-masing 
partisipan secara bebas. Masing-masing partisipan menyampaikan alasan pilihan gambar dan karakter yang disimbolkan oleh gambar tersebut. Partisipan juga harus memberikan alasan pada gambar yang tidak dipilihnya. Pada akhir FGD, partisipan diminta untuk menyampaikan apakah mereka mempunyai karakter-karakter tersebut.

Tahapan kedua adalah pelatihan pembuatan dan pengemasan bawang goreng. Kegiatan ini membutuhkan waktu setengah hari. Tujuan kegiatan ini adalah memberikan pengalaman bagi partisipan untuk melakukan produksi dan mengemas produk premium. Produk premium mempunyai target pasar yaitu wisatawan. Wisatawan adalah konsumen yang bersifat irasional. Proses produksi dan kemasan bawang merah ditunjukkan pada Gambar 1.

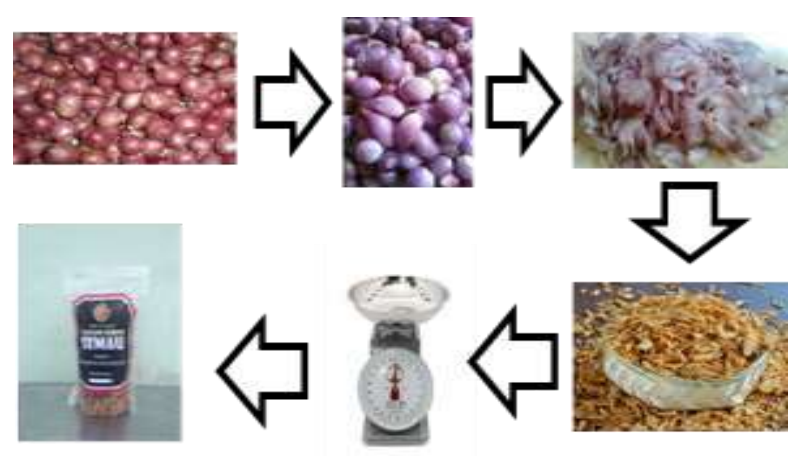

Gambar 1. Proses Produksi dan Kemasan Bawang Goreng

Gambar 1 di atas menunjukkan proses produksi mulai dari: (i) bawang merah yang sudah dibersihkan oleh petani, pengupasan bawang merah, (iii) pengirisan, (iv) penggorengan setelah diberi bumbu sesuai formula resep, dan terakhir (v) pengemasan. Kemasan bawang goreng menggunakan merek daerah Semau. Warna kemasan didasarkan pada bungtilu atau bunga tiga warna yang menjadi warna khas kain adat tiga suku yang ada di Semau, yaitu: hitam, merah dan putih. Warna hitam merupakan warna kain adat suku Helong (penduduk asli). Merah dan putih adalah warna kain adat masing-masing suku Timor dan Rote. Ini bertujuan untuk memberikan kebanggaan tersendiri bagi masyarakat Semau.

Tahapan ketiga adalah in-depth interview. In-depth interview dilakukan pada partisipan tertentu. Partisipan-partisipan tersebut dipilih dari kegitan pada tahapan pertama. Pemilihan partisipan ini didasarkan pada adanya minimal satu karakter dasar pengusaha yang dimiliki oleh partisipan serta jiwa kepemimpinan yang menonjol pada partisipan bersangkutan. Partisipanpartisipan tersebut diharapkan dapat menjadi influencer bagi masyarakat Semau. In-depth interview bertujuan untuk mengetahui kemauan partisipan menjadi pengusaha bawang goreng. Partisipan diminta pendapatnya mengenai tingkat kesulitan, penetapan harga jual, dan pemasaran produk. Tingkat kesulitan dalam memproduksi bawang goreng mulai dari penggunaan timbangan, menerapkan resep pembuatan bawang goreng sampai dengan pengemasan. Pertanyaan ini bertujuan untuk memastikan partisipan mau memproduksi bawang goreng karena mudah. Penetapan harga jual produk bawang goreng dengan kemasan 75 gram. Pertanyaan ini bertujuan untuk memastikan kemampuan partisipan dalam menetapkan harga jual yang tidak melebihi biaya produksi atau memberikan keuntungan. Pemasaran produk. Partisipan diminta memberikan pendapat mengenai cara mereka dalam memasarkan produknya. Pertanyaan ini untuk memastikan kemampuan partisipan dalam mencari pasar.

Ketiga kegiatan di atas merupakan metode community development yang mampu mengubah pola pikir masyarakat Semau dari yang hanya menanam dan atau mengambil dari alam menjadi pola pikir kreatif dan inovatif sebagai pengusaha. 


\section{HASIL DAN PEMBAHASAN}

Pelaksanaan pengabdian pada masyarakat Semau ini dalam 3 kegiatan yaitu: FGD, pembuatan dan pengemasan bawang goreng, serta in-depth interview. FGD diikuti oleh 30 orang partisipan yang terdiri dari 25 orang ibu-ibu rumah tangga dan sisanya bapak-bapak. Partisipan dibagi dalam 5 kelompok. 5 kelompok diskusi ini dipandu oleh seorang fasilitator. FGD ini menggunakan 14 gambar yang mewakili 7 karakter wirausaha. Setiap partisipan diminta untuk memilih dan menceritakan pendapatnya. Partisipan memilih 11 dari 14 gambar yang menggambarkan karakter wirausaha.

Hasil wawancara dan diskusi mengenai opini partisipan tentang peraga/gambar yang menggambarkan 7 karakter wirausaha yaitu percaya diri, orientasi pada tugas dan hasil, pengambil risiko, kepemimpinan, orisinalitas/berbeda dari sebelumnya, orientasi masa depan, dan jujur.

Percaya diri. Percaya diri masyarakat Semau dicirikan dengan berani dan tangguh, mampu menguasai situasi, berani mengambil risiko dan rela berkorban.

Berorientasi pada hasil. Karakter utama wirausaha yang berorientasi tugas dan hasil masyarakat Semau dicirikan dengan sifat mengutamakan kebersamaan, saling menopang, keseimbangan, pekerja keras serta memahami saat-saat menang dan kalah.

Pengambil risiko. Pemaknaan masyarakat Semau terhadap risiko adalah hal yang baik untuk perjuangan, mempunyai tujuan, tantangan harus dihadapi, mencari hidup yang lebih baik, penuh dengan inovasi, ulet.

Kepemimpinan. Wirausaha adalah seorang pemimpin. Hasil eksplorasi menunjukkan bahwa pemimpin dimaknai sebagai seorang yang dapat menjadi penengah bagi beberapa pihak dan mampu menyelesaikan persoalan antar kelompok dalam lingkungannya serta seseorang yang memiliki inisiatif tinggi untuk melakukan perubahan.

Orisinalitas atau berbeda dari sebelumnya. Berdasarkan pemilihan gambar karakter orisinalitas belum nampak pada berbagai diskusi dan eksplorasi. Tataran pengetahuan masyarakat masih sebatas menerima dan mencontoh yang sudah ada. Kondisi ini dapat dimaknai bahwa perlu adanya suatu program khusus yang lebih fokus pada pengembangan imajinasi dan olah pikir masyarakat.

Beorientasi masa depan. Orientasi tugas masa depan dimaknai sebagai wirausaha adalah orang yang mempunyai mimpi (tujuan), mencari uang (keuntungan) dengan bekerja keras, tidak memboroskan uang, mamu berpikir untuk berjaga jaga yaitu dengan memiliki tabungan dan investasi.

Jujur dan tekun. Karakter jujur dan tekun dalam masyarakat semau dalam mengekspresikan diri sebagai wirausaha adalah seorang yang rela melayani dengan ketulusan. Tidak mengambil hak dan atau milik orang lain untuk dikuasai baik secara individu maupun kelompok.

Partisipan telah mempunyai 6 karakter wirausaha yaitu: percaya diri, berorientasi pada tugas dan hasil, pengambil risiko, kepemimpinan, berorientasi masa depan, serta jujur dan tekun. Hal ini sudah dapat menjadi modal bagi masyarakat Semau untuk menjadi pengusaha. Sedangkan karakter orisinalitas/berbeda dengan yang sebelumnya masih belum dimiliki oleh masyarakat Semau. Hal ini menunjukkan bahwa masyarakat Semau masih belum cukup inovatif dalam menghasilkan produk unggulan yang berbeda dibandingkan dengan daerah yang lain. Oleh karena itu, masyarakat Semau masih membutuhkan pendampingan 
berkelanjutan dalam mengembangkan karakter kewirausahaannya.

Kegiatan kedua adalah pelatihan pembuatan dan pengemasan bawang goreng. Formulasi untuk membuat bawang merah goreng telah melalui dua pengujian yaitu uji laboratorium dan uji pasar. Uji laboratorium menunjukkan kadar air bawang goreng Semau 3,11\%. Ini tergolong rendah (Alam dkk, 2014). Kadar air merupakan parameter penting pada produk bawang goreng. Uji pasar dilakukan terhadap 15 orang yang membutuhkan dan mengetahui produk bawang merah goreng. Uji pasar dilakukan melalui uji rasa, bentuk, warna, tekstur, aroma dan kesediaan untuk membeli dengan harga tertentu. Formulasi bawang merah yang sudah teruji ini dipakai sebagai formulasi yang diajarkan untuk dibuat dalam pelatihan ini.

Pelatihan pembuatan bawang goreng dilakukan dalam dua tahapan, yaitu pertama, tutorial mengenai (i) peralatan-peralatan yang digunakan untuk menimbang, mengiris, dan menggoreng bawang merah, serta (ii) resep atau formula yang akan digunakan untuk membuat bawang goreng. Kedua adalah praktek membuat dan mengemas bawang goreng.

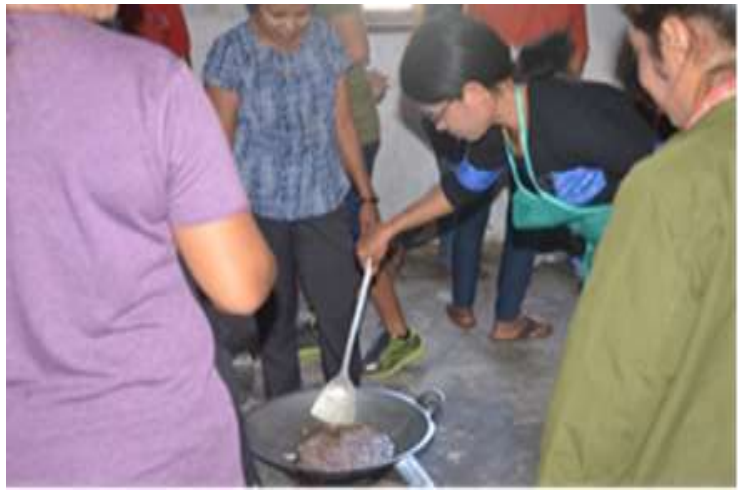

Gambar 2. Pembuatan Bawang Goreng

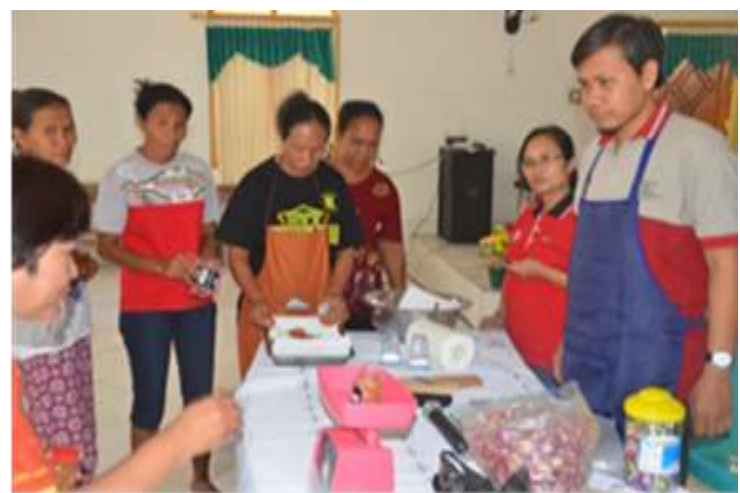

Gambar 3. Pengemasan Barang Goreng

Gambar 2 dan 3 menunjukkan kegiatan pelatihan pembuatan dan pengemasan bawang goreng. Partisipan bersemangat dalam mengikuti kegiatan pelatihan ini. Partisipan mengalami kesulitan pada saat menggunakan timbangan untuk bawang mentah dan untuk pengemasan bawang goreng. Oleh karena itu, latihan untuk menggunakan peralatan dibutuhkan oleh masyarakat sehingga mereka terbiasa dalam menggunakannya. Sedangkan kegiatan menggoreng merupakan hal mudah bagi partisipan karena mereka sudah terbiasa melakukannya.

Kegiatan terakhir dalam pengabdian kepada masyarakat ini adalah in-depth interview yang bertujuan untuk mengetahui pendapat partisipan dalam menjalankan kegiatan produksi bawang goreng di masa mendatang. In-depth interview diikuti oleh 5 orang partisipan yang menjadi wakil tiap kelompok.

Hasil in-depth interview mengenai: pertama, tingkat kesulitan dalam memproduksi bawang goreng. Partisipan berpendapat bahwa membuat bawang goreng cukup mudah. Kesulitan lebih pada penggunaan alat untuk menimbang dan mengiris bawang merah. Irisan bawang yang harus sama ketebalannya cukup menyulitkan partisipan. Partisipan mengalami kesulitan dalam menggunakan timbangan untuk 
mengemas bawang goreng dengan berat neto 75 gram.

Kedua, penetapan harga jual bawang goreng dengan kemasan 75 gram. Partisipan berpendapat bahwa untuk menetapkan harga jual cukup mudah. Perhitungan didasarkan pada total biaya yang dikeluarkan ditambah keuntungan yang mereka inginkan.

Ketiga, pemasaran produk. Partisipan mempunyai ide menarik dalam memasarkan produk bawang gorengnya, yaitu melalui pertemuan-pertemuan rutin keluarga, arisan, dan atau acara-acara yang diadakan oleh pemerintah kabupaten dan kecamatan.

Masyarakat Semau mempunyai kapabilitas dalam melakukan produksi bawang goreng. Dalam wawancara ini, pewawancara juga menanyakan mengenai upaya partisipan dalam mengatasi masalah orisinalitas produk. Karakter orisinal atau berbeda dari yang sebelumnya dari hasil kegiatan FGD menunjukkan bahwa karakter ini belum dimiliki oleh partisipan. Pertanyaan yang diajukan adalah mengapa konsumen harus membeli produk bawang goreng dari Semau? Seorang partisipan memberikan jawaban tepat yaitu bawang goreng Semau akan dibuat dalam berbagai varian rasa seperti: balado atau pedas. Hasil diskusi pada sesi in-depth interview menyepakati produk bawang goreng Semau dibuat dalam dua rasa yaitu: original dan balado (pedas). Produk bawang goreng ini dapat menjadi produk unggulan daerah, karena Semau merupakan salah satu daerah penghasil bawang merah yang berkualitas di Indonesia.

\section{PENUTUP}

\section{Simpulan}

Masyarakat Semau sudah mempunyai modal untuk menjadi pengusaha. Ini ditunjukkan dengan adanya 6 karakter yang telah dimiliki oleh partisipan kegiatan ini, yaitu: percaya diri, berorientasi tugas, pengambil risiko, kepemimpinan, berorientasi pada masa depan, serta jujur dan tekun. Karakter orisinalitas atau berbeda dari yang sebelumnya masih harus digali dan diinspirasikan lebih lanjut. Oleh karena itu, metode pendampingannya secara berkelanjutan.

\section{Saran}

Kegiatan ini menghasilkan metode produksi yang memberdayakan ibu-ibu rumah tangga di Semau. Ibu-ibu yang menjadi partisipan membuat produk bawang goreng sesuai dengan formula resep. Bawang goreng tersebut dikirimkan ke koordinator untuk proses pengemasan. Kemasan yang dikeluarkan atau dijual ke pasar di bawah satu merek yaitu merek Semau. Koordinator bawang goreng melakukan koordinasi dengan gereja dan kelurahan untuk proses pemasaran. Metode ini akan diterapkan sampai individu-individu mempunyai kemandirian untuk melakukan usaha.

Pendampingan berkelanjutan yang dilakukan dalam dua bentuk online dan offline. Secara online, pendampingan dilakukan melalui media sosial: whatapps, dan facebook. Sedangkan pendampingan secara offline, dilakukan dalam bentuk kunjungan ke pulau Semau. Pendampingan berkelanjutan ini mempunyai tujuan utama yaitu: memastikan kualitas produk dan pemasarannya. Kendala-kendala yang dihadapi oleh masyarakat dapat dicarikan solusinya melalui pendampingan berkelanjutan ini.

\section{Ucapan Terima Kasih}

Kami mengucapkan terima kasih kepada Klasis Gereja Masehi Injili Timor (GMIT), Camat Semau dan Camat Semau Selatan serta Kepala Desa Otan yang telah membantu pelaksanaan kegiatan pengabdian kepada masyarakat ini. 


\section{E. DAFTAR PUSTAKA}

Alam N., Rostiati, dan Murhadi. Sifat fisikkimia dan arganoleptik bawang goreng Palu pada berbagai frekuensi pemakaian minyak goreng. Agritech, 34 (4): $390-398$

Drucker, P.F. 1985. Innovation and Entrepreneurship: Practice and Principle. Perfect Bound, New York. 100

Gunadhi, E. 2013. Kewirausahaan. STT. Garut. 17

Khoo-Lattimore, C., M. Thyne, dan K. Robertson. 2009. The ZMET method: using projective technique to understand consumer home choice. The Marketing Review. 9 (2): 139 154

Phillips, R., dan R. H. Pittman. 2009. A Framework of Community and Economic Development. In: an Introduction of Community Development. Routledge, New York. 5

Sandiasa, G. 2009. Kewirausahaan. Fakultas Ilmu Sosial dan Ilmu Politik. Universitas Panji Sakti. Singaraja. 10

Salim, L. 2008. Store Loyalty Determinants of Modern Retailing in Indonesia: a Structural Equation Modelling (SEM) Approach. Disertasi. Universiti Utara Malaysia. Available from:

URL: http://etd.uum.edu.my/1283/

Schiffman, L., dan K. Leslie. 2007. Consumer Behaviour. Prentice Hall, International. 511
Suryana. 2001. Kewirausahaan. Salemba Empat, Jakarta. 8

Tulipa, D., D. Rachmawati, dan L. Ellitan. 2017. Laporan Hasil Survei Semau 27 - 29 Oktober 2017. LPPM, Universitas Katolik Widya Mandala Surabaya.

Vincent II, J.W. 2009. Community Development Assessment. In: an Introduction of Community Development. Routledge, New York. 138 